\title{
Combining remote sensing and GIS climate modelling to estimate daily forest evapotranspiration in a Mediterranean mountain area
}

\author{
J. Cristóbal ${ }^{1,4}$, R. Poyatos ${ }^{2}$, M. Ninyerola ${ }^{1}$, P. Llorens ${ }^{3}$, and X. Pons ${ }^{4}$ \\ ${ }^{1}$ Department of Animal Biology, Plant Biology and Ecology, C-Building, Universitat Autònoma de Barcelona, \\ Cerdanyola del Vallès, 08193, Spain \\ ${ }^{2}$ Center for Ecological Research and Forestry Applications (CREAF), Universitat Autònoma de Barcelona, \\ Cerdanyola del Vallès, 08193, Spain \\ ${ }^{3}$ Institute of Environmental Assessment and Water Research (IDÆA), CSIC, Jordi Girona, 18, Barcelona, 08034, Spain \\ ${ }^{4}$ Department of Geography, B-Building, Universitat Autònoma de Barcelona, Cerdanyola del Vallès, 08193, Spain
}

Received: 13 December 2010 - Published in Hydrol. Earth Syst. Sci. Discuss.: 25 January 2011

Revised: 26 April 2011 - Accepted: 7 May 2011 - Published: 25 May 2011

\begin{abstract}
Evapotranspiration monitoring allows us to assess the environmental stress on forest and agricultural ecosystems. Nowadays, Remote Sensing and Geographical Information Systems (GIS) are the main techniques used for calculating evapotranspiration at catchment and regional scales. In this study we present a methodology, based on the energy balance equation (B-method), that combines remote sensing imagery with GIS-based climate modelling to estimate daily evapotranspiration $\left(\mathrm{ET}_{\mathrm{d}}\right)$ for several dates between 2003 and 2005. The three main variables needed to compute $\mathrm{ET}_{\mathrm{d}}$ were obtained as follows: (i) Land surface temperature by means of the Landsat-5 TM and Landsat-7 ETM+ thermal band, (ii) air temperature by means of multiple regression analysis and spatial interpolation from meteorological ground stations data at satellite pass, and (iii) net radiation by means of the radiative balance. We calculated $\mathrm{ET}_{\mathrm{d}}$ using remote sensing data at different spatial and temporal scales (Landsat-7 ETM+, Landsat-5 TM and TERRA/AQUA MODIS, with a spatial resolution of 60,120 and $1000 \mathrm{~m}$, respectively) and combining three different approaches to calculate the $B$ parameter, which represents an average bulk conductance for the daily-integrated sensible heat flux. We then compared these estimates with sap flow measurements from a Scots pine (Pinus sylvestris L.) stand in a Mediterranean mountain area. This procedure allowed us to better understand the limitations of $\mathrm{ET}_{\mathrm{d}}$ modelling and how it needs to be improved, especially in heterogeneous forest areas. The method
\end{abstract}

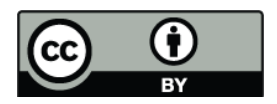

Correspondence to: J. Cristóbal (jordi.cristobal@uab.cat) using Landsat data resulted in a good agreement, $R^{2}$ test of 0.89 , with a mean RMSE value of about $0.6 \mathrm{~mm} \mathrm{day}^{-1}$ and an estimation error of $\pm 30 \%$. The poor agreement obtained using TERRA/AQUA MODIS, with a mean RMSE value of 1.8 and $2.4 \mathrm{~mm} \mathrm{day}^{-1}$ and an estimation error of about \pm 57 and $50 \%$, respectively. This reveals that $\mathrm{ET}_{\mathrm{d}}$ retrieval from coarse resolution remote sensing data is troublesome in these heterogeneous areas, and therefore further research is necessary on this issue. Finally, implementing regional GIS-based climate models as inputs in $\mathrm{ET}_{\mathrm{d}}$ retrieval have has provided good results, making possible to compute $\mathrm{ET}_{\mathrm{d}}$ at regional scales.

\section{Introduction}

Evaporation and transpiration are the two main processes involved in water transfer from vegetated areas to the atmosphere. Evapotranspiration (ET) from the Earth's vegetation constitutes $88 \%$ of the total terrestrial evapotranspiration, and returns more than $50 \%$ of terrestrial precipitation to the atmosphere (Oki and Kanae, 2006); therefore it plays a key role in both the hydrological cycle and the energy balance of the land surface. Climate warming may accelerate the hydrological cycle as a result of enhanced evaporative demand in some regions where water is not limiting (Jung et al., 2010). However, the combination of warmer temperatures with constant or reduced precipitation in other regions may lead to a large decrease in water availability for natural and agricultural systems as well as for human needs (Jackson

Published by Copernicus Publications on behalf of the European Geosciences Union. 
et al., 2001), especially in arid or semiarid areas (Jung et al., 2010) such as the Mediterranean basin (Bates et al., 2008).

Evapotranspiration has been measured extensively at local scales using micrometeorological (such as eddy-covariance or the Bowen ratio) or sap flow techniques. Since the last decade, there have been several global initiatives to monitor evapotranspiration in different vegetation types, such as FLUXNET (ORNL DAAC, 2010). Therefore, magnitudes and controls (climate, water availability, physiological regulation, etc.) on evapotranspiration are widely known for different types of vegetation, albeit at small spatial scales. How can we improve, then, our knowledge of evapotranspiration? In terms of spatial variability (and its driving factors) the next challenge is larger scales.

ET can be modelled at global scales using GIS climatebased methodologies such as GIS-based Environmental Policy Integrated Climate - GEPIC - (Liu et al., 2007, 2009), Lund-Potsdam-Jena managed Land - LPJmL - (Rost et al., 2008) or Global Crop Water Model - GCWM - (Siebert and Döll, 2010). However, radiometric measurements provided by remote sensing added to GIS-based climate modelling have proved to be essential for modelling ET because they are the only techniques that allow us to compute it feasibly at both regional (Cristóbal et al., 2005; Kustas and Norman, 1996) and global scales (Mu et al., 2007). Moreover, the use of remote sensing techniques supplements the frequent lack of ground-measured variables and parameters that are required for applying the local models at a regional scale (Sánchez et al., 2008a).

Currently, there are a wide variety of remote sensing models for calculating ET at global or regional scales, such as METRIC (Allen et al., 2007), SEBAL (Bastiaanssen et al., 1998), TSEB (Kustas and Norman, 2000), ALEXI/disALEXI (Anderson et al., 2004), S-SEBI (Roerink et al., 2000), STSEB (Sánchez et al., 2008b) and the BMethod (Jackson et al., 1977; Seguin and Itier, 1983); other methodologies can be found in Schmugge et al. (2002) or Sánchez et al. (2008a). All these theoretical methods used to estimate ET at a regional scale with remote sensing techniques are derived from the energy balance equation based on the principle of energy conservation in a system formed by soil and vegetation. Most of them try to minimize the inputs from ancillary data (often data from ground meteorological stations) in order to make the algorithms more operational at global scales. However, there is currently no agreement on which method is the most appropriate because this often depends on the application purposes.

Most of these methods have been validated in homogeneous covers (crops or natural vegetation) and flat areas, where a single meteorological station record is used to describe the climate conditions of a large area. In these areas, the use of moderate or coarse spatial resolution remote sensing data is enough to obtain accurate daily $\mathrm{ET}\left(\mathrm{ET}_{\mathrm{d}}\right)$ results. However, in more complex and heterogeneous areas, due to the landscape, orographic or climatic variability, a single meteorological record or remote sensing data with coarse spatial resolution may not be accurate enough to calculate the $\mathrm{ET}_{\mathrm{d}}$. Operative GIS climate-based techniques can be used at regional scales in both simple and complex areas (Ninyerola et al., 2007; Pons and Ninyerola, 2008) to achieve higher accuracy and provide the input variables for agriculture and natural vegetation evapotranspiration modelling.

The objective of this paper is to evaluate a simple method for computing daily ET using stand-scale sap flow measurements made in Scots Pine (Pinus sylvestris L.) in a heterogeneous Mediterranean mountain area during a three year period. GIS climate-based regional modelling was used instead of a single meteorological measurement to obtain the meteorological inputs (air temperature and solar radiation) in order to evaluate the performance of this technique. Low (TERRA/AQUA MODIS) and moderate (Landsat-TM/ETM+) spatial resolution remote sensing images were used as the remote sensing inputs in order to evaluate their accuracy in a heterogeneous landscape.

\section{Data and methods}

\subsection{Study area}

The study plot is located within the Vallcebre research catchments (Gallart et al., 2005; Latron et al., 2010; Llorens et al., 2010), $42^{\circ} 12^{\prime} \mathrm{N}, 1^{\circ} 49^{\prime} \mathrm{E}$, located in the eastern Pyrenees (NE Iberian Peninsula). It has a humid Mediterranean climate, with a marked water deficit in summer. The mean annual temperature at $1260 \mathrm{~m}$ is $9.1^{\circ} \mathrm{C}$, and the long term (1983-2006) mean annual precipitation is $862 \pm 206 \mathrm{~mm}$, with a mean of 90 rainy days per year. The long term (1989-2006) mean annual reference evapotranspiration, calculated using the Hargreaves and Samani (1982) method, was $823 \pm 26 \mathrm{~mm}$. Mudstone and limestone substrates are predominant, resulting in clay soils in the first case, and bare rock areas or thin soils in the latter (Gallart et al., 2002). The vegetation in the area is sub-Mediterranean oak forest (Buxo-sempervirentis-Quercetum pubescentis association), but most of the land was terraced and deforested for cultivation in the past, and then progressively abandoned during the second half of the twentieth century. The present landscape is mainly a mosaic of mesophylous grasslands and patches of Scots pine, which colonized old agricultural terraces after they were abandoned (Poyatos et al., 2003). Figure 1 shows the location of the Vallcebre research catchments.

\subsection{Meteorological and remote sensing data}

We used two sources of meteorological data to fit and validate the models. In the case of the Scots pine stand, air temperature (HMP35C, Vaisala, Vantaa, Finland), wind speed (A100R, Vector InstrumentsRhyl, UK) and net radiation (NR-Lite ,Kipp \& Zonen, Delft, The Netherlands) were 


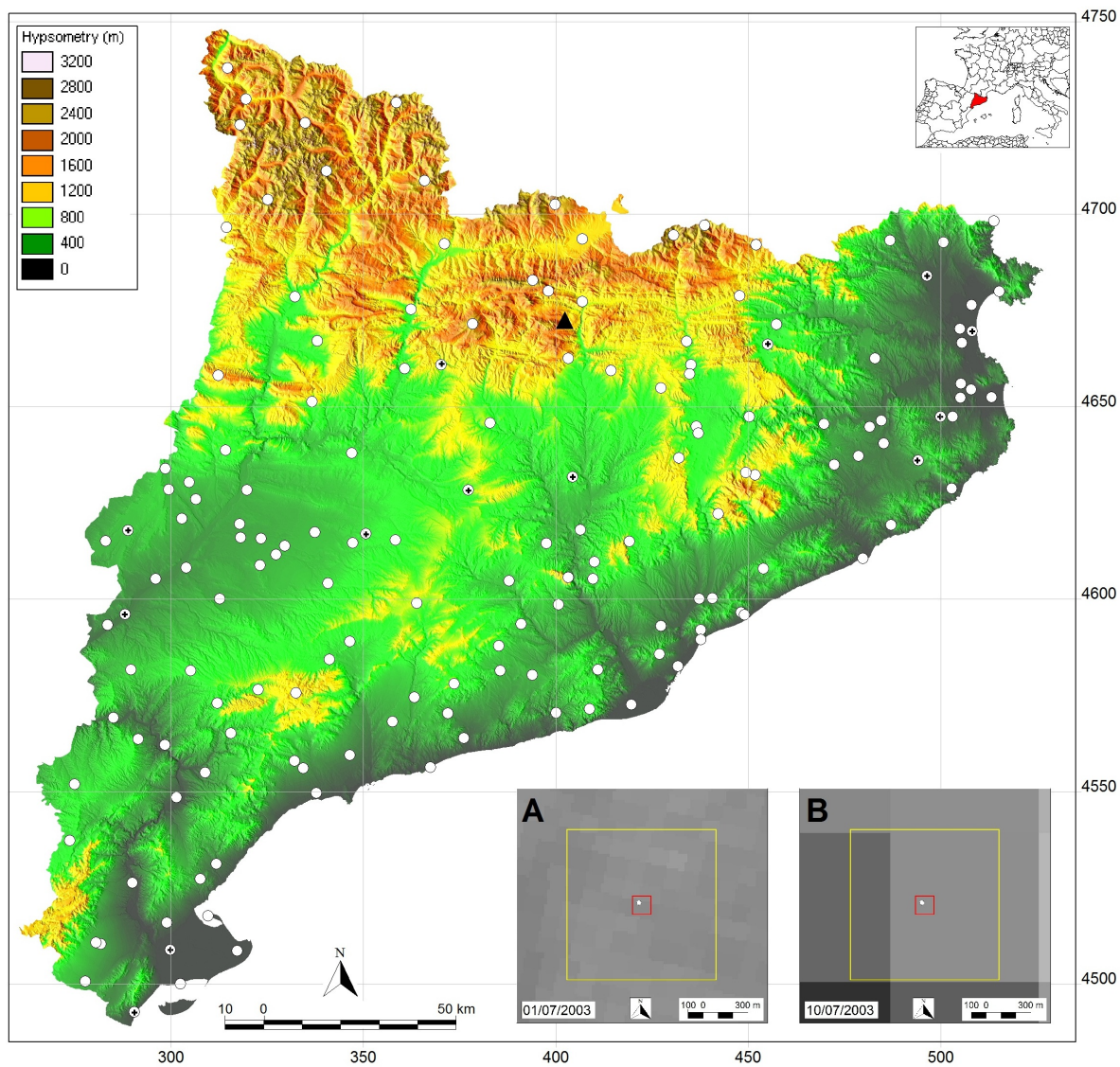

Fig. 1. Location of SMC meteorological stations and Vallcebre research catchments in Universal Transversal Mercator (UTM) projection (UTM coordinates are expressed in $\mathrm{km}$ ). The white dots are meteorological stations from the SMC that include air temperature sensors, the black dots are meteorological stations from the SMC that include net radiation sensors, and the black triangle indicates the Vallcebre research catchments. Panel (A) is the Landsat-TM LST of 1 July 2003 and panel (B) is the TERRA MODIS LST of 10 July 2003 of the Vallcebre research catchments (black triangle). The red square represents a Landsat-TM thermal band pixel (120 m) and the yellow square represents a TERRA MODIS thermal band pixel $(1000 \mathrm{~m})$. In panels $(\mathbf{A})$ and $(\mathbf{B})$ the white dot is the Scots pine stand.

measured at a height of $2 \mathrm{~m}$ above the canopy. Data were recorded every $10 \mathrm{~s}$ and stored as 15 -min averages in a datalogger, DT500, DataTaker, Australia (Poyatos et al., 2005).

In the case of air temperature and net radiation regionalization, meteorological data from 161 meteorological stations were downloaded from the Catalan Meteorological Service (SMC) web (meteorological data available at http://www. meteocat.com). Figure 1 shows the spatial distribution of these two sources of meteorological data.

A set of 30 TERRA-MODIS images and 27 AQUAMODIS images and a set of 11 Landsat-7 ETM+ and 10 Landsat-5 TM images from paths 197 and 198, row 31 were selected to perform the $\mathrm{ET}_{\mathrm{d}}$ modelling of the Scots Pine forest stand from 2003 to 2005 . In order to avoid canopy interception and to make sap-flow measurements fully representative of ET canopy we selected clear sky dates where no precipitation was present during at least 15 days before and after the selected day. Figure 2 shows the temporal distribution of the selected dates aggregated by month.
AQUA/TERRA MODIS images were downloaded using the Land Processes Distributed Active Archive Center gateway (https://wist.echo.nasa.gov/ wist/api/imswelcome/). We selected three different types of products which contain the remote sensing data to calculate the $\mathrm{ET}_{\mathrm{d}}$ : MOD11A1 and MYD11A1 (which contain TERRA and AQUA daily land surface temperature, LST, and emissivity respectively), MOD09GHK and MYD09GHK (which contain TERRA and AQUA daily reflectances, respectively), and MOD05 (which contains daily water vapour). Although image time acquisition is different for each satellite, Landsat and TERRA satellites pass over Catalonia at a similar time, between 09:30 and 10:30 LST (local solar time). AQUA passes over the same area, but between 13:00 and 14:00 LST. 


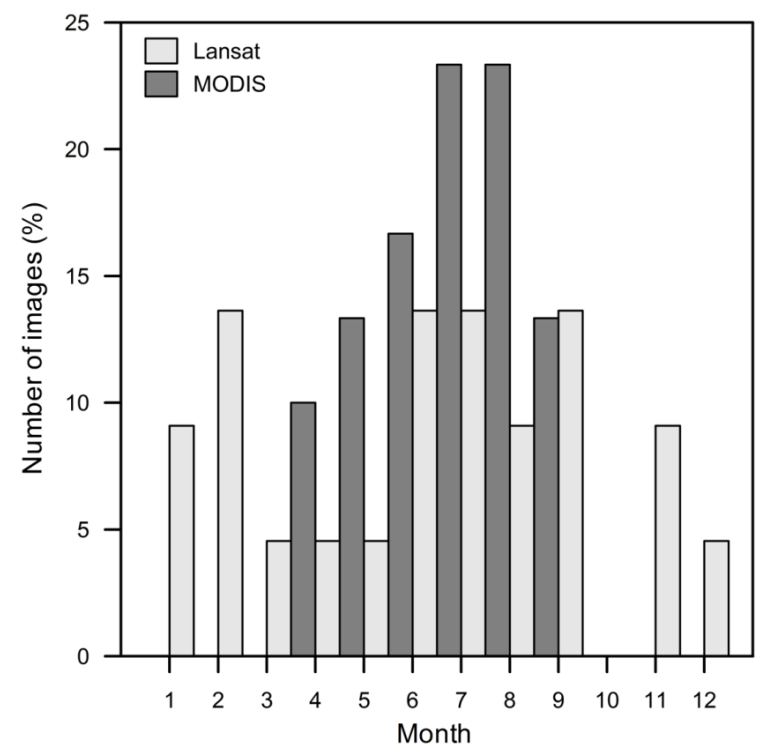

Fig. 2. Monthly temporal distribution of satellite data (clear sky and without bow tie effect: an artefact of the arrangement of sensors on the MODIS instrument, in which the scans are partially overlapping at off nadir angles) used during the period 2003-2005.

\subsection{The evapotranspiration model}

We used the B-method to compute $\mathrm{ET}_{\mathrm{d}}$. This methodology is derived from the model proposed by Jackson et al. (1977), which is based on the energy balance equation and has been used or modified for both natural vegetation and crop areas by different authors (Caselles et al., 1992, 1998; García et al., 2007; Sánchez et al., 2007, 2008a; Seguin and Itier, 1983; Vidal and Perrier, 1989). Seguin and Itier (1983) proposed a modified equation that needs net radiation $\left(R_{\mathrm{n}}\right)$ and the difference between LST and air temperature at satellite pass $\left(T_{i}\right)$ as input variables:

$\mathrm{ET}_{\mathrm{d}}=R_{\mathrm{nd}}-B\left(\mathrm{LST}-T_{i}\right)^{n}$

where subindex $\mathrm{d}$ is the daily periods, ET and $R_{\mathrm{n}}$ are in mm day ${ }^{-1}$ and both temperatures are in K. Exponent $n$ is a correction for non-neutral static stability that could be assigned to one, as Seguin and Itier (1983) suggested. Since daily integration of soil heat flux is likely to be close to zero, Eq. (1) expresses the daily integrated surface sensible heat flux into the atmosphere (Allen et al., 1998; Carlson and Buffum, 1989; Seguin and Itier, 1983). Due to the importance of the $B$ parameter in calculating $\mathrm{ET}_{\mathrm{d}}$, we used two approaches to compute $B$.

$B$ can be defined as an exchange coefficient that in Eq. (1) represents an average bulk conductance for the dailyintegrated sensible heat flux. This term is related to the sensible heat flux $(H)$, one of the most difficult variables to determine in the energy balance equation (Bastiaanssen et al., 1998). There are several approaches that use LST directly, such as the parallel resistance model developed by Norman et al. (1995), and the one developed by Caselles et al. (1992), which is adapted for heterogeneous areas and defined by the following equation:

$$
B=\left(\frac{R_{\mathrm{nd}}}{R_{\mathrm{ni}}}\right) \cdot\left(\frac{\rho C_{p}}{r_{\mathrm{a}}^{*}}\right)
$$

where subindex i means instantaneous and $\left(R_{\mathrm{nd}} / R_{\mathrm{ni}}\right)$ is called the $R_{\mathrm{n}}$ ratio. $\rho C_{p}$ is the volumetric heat capacity of air $\left(\mathrm{J} \mathrm{kg}^{-1} \mathrm{~K}^{-1}\right)$ and $r_{\mathrm{a}}^{*}$ is the effective aerodynamic resistance. Measurements of effective aerodynamic resistance are not usually easy to obtain; therefore, we considered the aerodynamic resistance of Pinus sylvestris to be equal to $28.1 \mathrm{~m} \mathrm{~s}^{-1}$, as determined by Sánchez et al. (2007), because our study area is similar to that of this previous work (J. S. Sánchez, personal communication, 2009).

In addition, $B$ can also be obtained using the simple equation proposed by Carlson et al. (1995), obtained from a soil-vegetation atmosphere transfer model that integrates the main factors on which $B$ depends, such as wind velocity and aerodynamic resistance; therefore, $B$ can also be defined as:

$B=0.109+0.51\left(\mathrm{NDVI}^{*}\right)$

where NDVI* is a scaled vegetation index based on the NDVI and is defined as:

$\mathrm{NDVI}^{*}=\frac{\mathrm{NDVI}_{p}-\mathrm{NDVI}_{0}}{\mathrm{NDVI}_{s}-\mathrm{NDVI}_{0}}$

where subindex $p$ is the image NDVI value for a given pixel, 0 is a bare soil pixel and $s$ is a fully vegetated pixel.

\subsection{ET $_{d}$ model inputs}

\subsubsection{Landsat and TERRA/AQUA image processing}

Landsat images were corrected using the methodology proposed by Palà and Pons (1995) that is based on a first-degree polynomial fit that accounts for the relief using a detailed enough Digital Elevation Model (DEM) obtained from the Cartographic Institute of Catalonia (ICC). This correction also requires a set of ground control points (GCP) that were digitized on screen from $2.5 \mathrm{~m}$ digital orthophotos (from the ICC). A planimetric accuracy (obtained with an independent set of GCP) of less than $15 \mathrm{~m}$ (half pixel) was obtained. Radiometric correction was carried out following the methodology proposed by Pons and Solé-Sugrañes (1994), which allows us to reduce the number of undesired artifacts due to the atmospheric effects or differential illumination that are results of the time of day, the location on the Earth and the relief (zones being more illuminated than others, shadows, etc). The digital numbers were converted to radiances by means of image header parameters, taking into account the considerations presented by Cristóbal et al. (2004) and Chander et al. (2009). 
AQUA/TERRA MODIS reflectance and LST and emissivity products were imported, with all the necessary metadata to process them. Before that, images were reprojected to UTM-31 N. The water vapour product was geometrically corrected using HEG-WIN software (http://newsroom.gsfc. nasa.gov/sdptoolkit/HEG/HEGDownload.html).

\subsubsection{Air temperature}

Different air temperature input variables are needed to compute net radiation $\mathrm{LST}$ and $\mathrm{ET}_{\mathrm{d}}$ : satellite pass air temperature $\left(T_{i}\right)$, daily mean air temperature $\left(T_{\mathrm{a}}\right)$ and daily minimum air temperature $\left(T_{\min }\right)$. To regionalize air temperature, we applied a multiple regression analysis with spatial interpolation of residual errors of ground meteorological station data using geographical variables as predictors, such as altitude, latitude, or continentality (Cristóbal et al., 2008; Ninyerola et al., 2000, 2007). Spatial interpolation of the residuals has been computed using the Inverse Distance Weighted interpolation because this interpolator offers better results than other methodologies, at least in the case of air temperature modelling (Ninyerola et al., 2000). Air temperature data were fitted using $60 \%$ of the meteorological ground stations and cross-validated with the remaining $40 \%$. In these previous works, $T_{i}, T_{\mathrm{a}}$ and $T_{\min }$ were obtained with an RMSE of $1.8 \mathrm{~K}$, $1.3 \mathrm{~K}$ and $2.3 \mathrm{~K}$, respectively.

\subsubsection{Land surface temperature (LST) and emissivity (LSE)}

In the case of Landsat-5 TM and Landsat-7 ETM+, the LST was calculated with the methodology proposed by Cristóbal et al. (2009), which is based on the radiative transfer equation and needs air temperature and water vapour as input variables, and present a RMSE of about $1 \mathrm{~K}$ compared with radiosonde data. The methodology is designed for a wide range of water vapour values $\left(0\right.$ to $\left.8 \mathrm{~g} \mathrm{~cm}^{-2}\right)$ to take into account global conditions. The TERRA/AQUA MODIS water vapour product (MOD05) was used as the water vapour source. The air temperature was computed as explained in Sect. 4.2.

To compute LSE we used the NDVI Threshold Method proposed by Sobrino and Raissouni (2000) and Sobrino et al. (2008). This methodology uses certain NDVI thresholds to distinguish between bare soil, fully vegetated and mixed pixels. According to the authors it gives an error of $1 \%$ (Sobrino et al., 2008).

\subsubsection{Daily net radiation $\left(\boldsymbol{R}_{\mathrm{nd}}\right)$}

Instantaneous net radiation is usually computed with the energy balance equation as follows:

$R_{\mathrm{ni}}=R_{\mathrm{si} \downarrow} \cdot(1-\alpha)+\varepsilon_{\mathrm{a}} \cdot \sigma \cdot T_{i}^{4}-\varepsilon \cdot \sigma \cdot \mathrm{LST}^{4}$

where subindex i means instantaneous, $\alpha$ is the surface albedo, $R_{\mathrm{S} \downarrow}$ is the incoming short wave radiation, $\sigma$ is the
Stephan-Boltzmann constant; $\varepsilon$ is the surface emissivity and $\varepsilon_{\mathrm{a}}$ is the air emissivity. The three terms of Eq. (5) regard to incoming net shortwave radiation, incoming longwave radiation and outgoing longwave radiation, respectively. However, B-method needs $R_{\text {nd }}$ instead of $R_{\mathrm{ni}}$ as input. Therefore, in order to compute $R_{\text {nd }}$ we approached the three terms of Eq. (5) on a daily basis as follows:

$$
R_{\mathrm{nd}}=R_{\mathrm{sd}} \downarrow \cdot(1-\alpha)+L_{\mathrm{d}}^{\downarrow}-L_{\mathrm{d}}^{\uparrow}
$$

where $\alpha$ is the surface albedo, $R_{\mathrm{Sd} \downarrow}$ is the daily incoming short wave radiation, $L_{\mathrm{d}}^{\downarrow}$ is the daily incoming longwave radiation and $L_{\mathrm{d}}^{\uparrow}$ is the daily outgoing longwave radiation.

Albedo $(\alpha)$ was computed using the Liang (2001) methodology in the case of Landsat-5 TM and Landsat-7 ETM+ images, and the method by Liang et al. (1999) in the case of TERRA/AQUA MODIS images. Both methodologies use a weighted sum of visible, near infrared and medium infrared radiation, and according to the authors the error in estimating albedo is less than $2 \%$. Daily solar radiation $\left(R_{\mathrm{sd} \downarrow}\right)$ was obtained with the methodology proposed by Pons and Ninyerola (2008). Given a digital elevation model, we can calculate the incident solar radiation at each point during a particular day of the year taking into account the position of the Sun, the angles of incidence, the projected shadows, the atmospheric extinction and the distance from the Earth to the Sun at fifteen minute intervals. The diffuse radiation was estimated from the direct radiation and the exoatmospheric direct solar irradiance was estimated with the Page (1986) equation that Baldasano et al. (1994) fitted with information from Catalonia.

$L_{\mathrm{d}}^{\downarrow}$ was computed by means of the methodology proposed by Dilley and O'Brien (1998) that according to the authors shows a RMSE of $5 \mathrm{~W} \mathrm{~m}^{-2}$ and a $R^{2}$ of 0.99 in is computation.

$R_{\mathrm{L} \downarrow}=\alpha+\beta\left(\frac{T_{\mathrm{a}}}{T_{*}}\right)^{6}+\gamma \sqrt{\frac{w}{w_{*}}}$

where $\alpha, \beta$ and $\gamma$ are 59.38, 113.7 and 96.96, respectively; $w$ is the water vapour, in $\mathrm{kg} \mathrm{m}^{-2}, T^{*}$ is $273.16 \mathrm{~K}, w^{*}$ is $25 \mathrm{~kg} \mathrm{~m}^{-2}$ and $T_{\mathrm{a}}$ is daily mean air temperature.

Finally, $L_{\mathrm{d}}^{\uparrow}$ was modeled by means of the methodology proposed by Lagouarde and Brunet (1993) as follows:

$R_{\mathrm{L} \uparrow}=\varepsilon R$

where $\varepsilon$ is the land surface emissivity and $R$ is defined as:

$R=\sigma \int_{0}^{\tau}\left[T_{\min }+\alpha \Delta T \sin \left(\frac{\pi t}{D}\right)\right]^{4} \mathrm{~d} t$

where $\sigma$ is Stefan-Boltzmann constant $\left(5.67 \times 10^{-8} \mathrm{~W}\right.$ $\left.\mathrm{K}^{-4} \mathrm{~m}^{-2} \mathrm{~d}^{-1}\right), \Delta T$ is the difference between LST and $T_{\mathrm{a}}$ at satellite pass, $t$, (both in $\mathrm{K}$ ), $T_{\min }(\mathrm{K}), \alpha=1.13, D$ is the time difference between sunset and sunrise; and $\tau=24$ (for a $24 \mathrm{~h}$ period). 


\subsubsection{B parameter}

As we explained in Sect. 3, $B$ parameter was calculated with two approaches: the $R_{\mathrm{n}}$ ratio and NDVI. In the $R_{\mathrm{n}}$ ratio approach, we used two ways to compute the parameter: (1) a regional $R_{\mathrm{n}}$ ratio (hereafter referred to as the $B-R_{\mathrm{n}}$ ratio regional) with data from 13 meteorological stations of the SMC meteorological network, and (2) a local $R_{\mathrm{n}}$ ratio (hereafter referred to as the $B-R_{\mathrm{n}}$ ratio local) with data from the meteorological station above the Scots pine stand in the Vallcebre research catchments. We used these two data sources to evaluate whether a regional measurement of the $R_{\mathrm{n}}$ ratio provides similar results as a local measurement.

In the NDVI approach (hereafter referred to as the BNDVI), Carlson et al. (1995) suggested selecting NDVI values depending on the study area. In our case, bare soil and fully vegetated NDVI values were set to 0.1 and 0.7 for the entire dataset, as these values were realistic enough to simulate bare soil and full vegetation conditions over the study area.

\subsection{Sap flow measurements and upscaling to stand transpiration}

We compared remote sensing daily evapotranspiration estimates with sap flow measurements upscaled to stand transpiration. Sap flow density in the outer xylem was measured with $20 \mathrm{~mm}$ long heat dissipation probes constructed according to Granier (1985); 15-min averages of data collected every 10 seconds were stored in a datalogger (DT 500, DataTaker, Australia). Heat dissipation gauges were installed at breast height on the north-facing side of 12 Scots pine trees and were covered with reflective insulation to avoid the influence of natural temperature gradients in the trunk. Sap flow density measured in the outer xylem was corrected for radial variability in sap flow using correction coefficients derived from radial patterns of sap flow within the xylem measured with a multi-point heat field deformation sensor (Nadezhdina et al., 2002). A gravimetric analysis of wood cores was carried out to estimate sapwood depths in a sample of Scots pine trees, and a linear regression was obtained between the basal area and sapwood area of individual trees. Stand transpiration was then calculated by multiplying the average sap flow density within a diametric class by the total sapwood area of trees in that class. Instantaneous values (15-min averages) were then summed to compute daily stand transpiration. Further details on the methodology and results of sap flow measurements used in this study can be found in Poyatos et al. $(2005,2008)$.

\section{Results and discussion}

\subsection{B parameter}

The $B$ parameter showed different behaviour depending on the approach used. The $B-R_{\mathrm{n}}$ ratio local had a mean and standard deviation (s.d.) of 6.9 and $3.2 \mathrm{~W} \mathrm{~m}^{-2}$ respectively, in the case of Landsat dates (see Fig. 2), and a mean and s.d. of 10.8 and $2.2 \mathrm{~W} \mathrm{~m}^{-2}$ respectively, in the case of TERRA/AQUA dates. The $B-R_{\mathrm{n}}$ ratio regional displayed a mean and s.d. of 9.5 and $2.3 \mathrm{~W} \mathrm{~m}^{-2}$ respectively, in the case of Landsat dates, and a mean and s.d. of 12.8 and $2.4 \mathrm{~W} \mathrm{~m}^{-2}$ respectively, in the case of TERRA/AQUA dates. Finally, B-NDVI showed a mean and s.d. of 11.9 and $2.6 \mathrm{~W} \mathrm{~m}^{-2}$ respectively, in the case of Landsat dates, and a mean and s.d. of 12.6 and $2.6 \mathrm{~W} \mathrm{~m}^{-2}$ respectively, in the case of TERRA/AQUA dates.

B-NDVI was similar in Landsat and TERRA/AQUA dates, but not in the $B$ approach using the $R_{\mathrm{n}}$ ratio, especially in the case of the $B-R_{\mathrm{n}}$ ratio local. While on winter and autumn dates the $B-R_{\mathrm{n}}$ ratio local had small values (positive or negative) close to 0 , B-NDVI tended to show higher positive values. For example, $B$ computed on 11 January 2005, using the local $R_{\mathrm{n}}$ ratio gave a negative value close to $0 \mathrm{~W} \mathrm{~m}^{-2}$, whereas in the case of B-NDVI it was $11.8 \mathrm{~W} \mathrm{~m}^{-2}$. During these seasons we would expect low $B$ values due to the energy budget; therefore, this suggests that B-NDVI could be less sensitive in winter and autumn situations than the $B-R_{\mathrm{n}}$ ratio.

In the case of the $B-R_{\mathrm{n}}$ ratio, the $R_{\mathrm{n}}$ ratio is usually obtained from a net radiation sensor over the study area. Some authors have used a constant value of $0.3 \pm 0.02$ (Seguin and Itier, 1983; Kustas et al., 1990; García et al., 2007) because most of the dates used in these studies were in spring or summer and over crop areas. However, we found that our local (Vallcebre research catchments) and regional (SMC meteorological stations) $R_{\mathrm{n}}$ ratios varied over the year (see Fig. 3). The local and regional $R_{\mathrm{n}}$ ratios for the Landsat/TERRA satellite pass had an annual mean (from 2003 to 2005 period) of $0.16 \pm 0.05$ (mean and s.d.) and $0.22 \pm 0.03$ respectively, and in the case of the AQUA satellite pass, an annual mean of $0.17 \pm 0.05$ and $0.21 \pm 0.02$ respectively. In addition, the $R_{\mathrm{n}}$ ratio varied little from 09:00 to 14:00 in our study area, and thus was useful in Landsat and TERRA/AQUA ET $\mathrm{d}_{\mathrm{d}}$ modelling. Therefore, we used a daily $R_{\mathrm{n}}$ ratio instead of a constant $R_{\mathrm{n}}$ ratio. This is in agreement with other authors who also reported a similar $R_{\mathrm{n}}$ ratio behaviour (Sánchez et al., 2007; Sobrino et al., 2005; Wassenaar et al., 2002). $R_{\mathrm{n}}$ ratio values reported in these studies are similar to the regional $R_{\mathrm{n}}$ ratio computed in our study area because our value was obtained at meteorological stations at a similar altitude as those in the literature. However, the local $R_{\mathrm{n}}$ ratio values are lower, which shows that this ratio does not only vary with latitude as Sánchez et al. (2007) suggests, but also with altitude. 
Table 1. (a): Descriptive statistics of daily net radiation $\left(\mathrm{Rn}_{\mathrm{d}}\right)$ and daily evapotranspiration $\left(\mathrm{ET}_{\mathrm{d}}\right)$ measured over the Scots pine stand, and Landsat Rn and $\mathrm{ET}_{\mathrm{d}}$ modelled using 3 methods: $B-R_{\mathrm{n}}$ ratio regional, $B-R_{\mathrm{n}}$ ratio local and $\mathrm{B}-\mathrm{NDVI}$ (see text). (b) Model validation results. s.d. is standard deviation, RMSE is root mean square error and MBE is mean bias error.

\begin{tabular}{|c|c|c|c|c|c|c|c|c|}
\hline & & \multirow[t]{3}{*}{$\begin{array}{c}\mathrm{Rn}_{\mathrm{d}} \\
\text { measured } \\
\left(\mathrm{W} \mathrm{m}^{-2}\right)\end{array}$} & \multirow[t]{3}{*}{$\begin{array}{c}\mathrm{Rn}_{\mathrm{d}} \\
\text { model } \\
\left(\mathrm{W} \mathrm{m}^{-2}\right)\end{array}$} & \multirow[t]{3}{*}{$\begin{array}{c}\mathrm{ET}_{\mathrm{d}} \\
\text { measured } \\
\left(\mathrm{mm} \mathrm{day}^{-1}\right)\end{array}$} & \multicolumn{3}{|c|}{$\begin{array}{c}\mathrm{ET}_{\mathrm{d}} \\
\text { modelled } \\
\left(\mathrm{mm} \mathrm{day}^{-1}\right)\end{array}$} & $n$ \\
\hline & & & & & \multicolumn{2}{|c|}{$B-R_{\mathrm{n}}$ ratio } & \multirow[t]{2}{*}{ B-NDVI } & \\
\hline & & & & & regional & local & & \\
\hline \multirow{4}{*}{ (a) } & Mean & 121 & 106 & 1.8 & 2.2 & 2.0 & 1.9 & \multirow{7}{*}{17} \\
\hline & s.d. & 60 & 62 & 0.6 & 0.3 & 1.0 & 1.1 & \\
\hline & $\min$ & 15 & 9 & 0.5 & 0.2 & 0.0 & 0.0 & \\
\hline & $\max$ & 194 & 186 & 2.7 & 2.1 & 3.3 & 3.7 & \\
\hline \multirow{3}{*}{ (b) } & RMSE & & 22 & & 0.7 & 0.5 & 0.6 & \\
\hline & MBE & & -15 & & 0.4 & 0.2 & 0.1 & \\
\hline & $R^{2}$ & & 0.89 & & 0.80 & 0.85 & 0.85 & \\
\hline
\end{tabular}

Table 2. (a): Descriptive statistics of daily net radiation $\left(\mathrm{Rn}_{\mathrm{d}}\right)$ and daily evapotranspiration $\left(\mathrm{ET}_{\mathrm{d}}\right)$ measured over the Scots pine stand, and TERRA MODIS Rn and $\mathrm{ET}_{\mathrm{d}}$ modelled using 3 methods $B-R_{\mathrm{n}}$ ratio regional, $B-R_{\mathrm{n}}$ ratio local and B-NDVI (see text). (b) Model validation results. s.d. is standard deviation, RMSE is root mean square error and MBE is mean bias error.

\begin{tabular}{|c|c|c|c|c|c|c|c|c|}
\hline & & \multirow[t]{3}{*}{$\begin{array}{c}\mathrm{Rn}_{\mathrm{d}} \\
\text { measured } \\
\left(\mathrm{W} \mathrm{m}^{-2}\right)\end{array}$} & \multirow[t]{3}{*}{$\begin{array}{c}\mathrm{Rn}_{\mathrm{d}} \\
\text { model } \\
\left(\mathrm{W} \mathrm{m}^{-2}\right)\end{array}$} & \multirow[t]{3}{*}{$\begin{array}{c}\mathrm{ET}_{\mathrm{d}} \\
\text { measured } \\
\left(\mathrm{mm} \mathrm{day}^{-1}\right)\end{array}$} & \multicolumn{3}{|c|}{$\begin{array}{c}\mathrm{ET}_{\mathrm{d}} \\
\text { modelled } \\
\left(\mathrm{mm} \mathrm{day}^{-1}\right)\end{array}$} & $n$ \\
\hline & & & & & \multicolumn{2}{|c|}{$B-R_{\mathrm{n}}$ ratio } & \multirow[t]{2}{*}{ B-NDVI } & \\
\hline & & & & & regional & local & & \\
\hline \multirow{4}{*}{ (a) } & Mean & 144 & 147 & 1.1 & 3.2 & 3.5 & 3.3 & \multirow{7}{*}{30} \\
\hline & s.d. & 28 & 42 & 0.8 & 1.5 & 1.5 & 1.5 & \\
\hline & $\min$ & 82 & 61 & 0.5 & 1.0 & 1.3 & 0.7 & \\
\hline & $\max$ & 188 & 247 & 2.7 & 6.1 & 6.4 & 6.8 & \\
\hline \multirow{3}{*}{ (b) } & RMSE & & 21 & & 1.8 & 2.0 & 1.9 & \\
\hline & MBE & & 3 & & 1.1 & 1.4 & 1.2 & \\
\hline & $R^{2}$ & & 0.77 & & 0.06 & 0.07 & 0.05 & \\
\hline
\end{tabular}

Further research into $R_{\mathrm{n}}$ ratio modelling in mountainous areas is therefore needed.

Moreover, it is worth remarking that the local $R_{\mathrm{n}}$ ratio obtained in the Scots pine stand displayed a different pattern to the regional $R_{\mathrm{n}}$ ratio because it had negative values on winter days when the $R_{\mathrm{n}}$ budget is negative, which often occurs in mountainous areas (Barry, 2001). ET $_{d}$ models do not usually predict this situation because they are generally applied in spring and summer and in relatively flat and low altitude areas.

\subsection{Daily net radiation validation}

The results show a good agreement between the $R_{\text {nd }}$ measured in the Scots pine stand and the $R_{\text {nd }}$ obtained using the Landsat regional model with an $R^{2}$ of 0.89 and an RMSE of $22 \mathrm{~W} \mathrm{~m}^{-2}$ (see Table 1 ). The $R_{\text {nd }}$ derived from TERRA/AQUA MODIS showed a similar RMSE but lower $R^{2}$ (0.77 and 0.73 respectively; Table 2$)$. It is worth noting that the proposed $\mathrm{R}_{n d}$ model developed with regional variables, such as $R_{\mathrm{sd} \downarrow}$, LST and $T_{\mathrm{a}}$, makes it possible to approximate this variable over large areas with a high level of accuracy.

\section{3 $\quad \mathbf{E T}_{\mathrm{d}}$ validation}

\subsubsection{Landsat}

In the $\mathrm{ET}_{\mathrm{d}}$ validation, we obtained a test $R^{2}$ of 0.84 when the $B$ parameter was estimated using a regional $R_{\mathrm{n}}$ ratio 


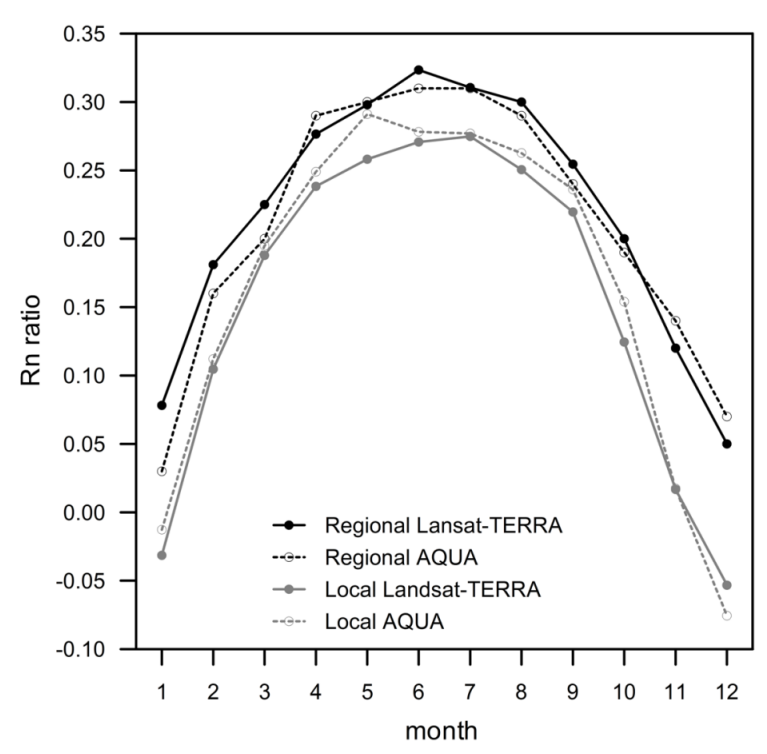

Fig. 3. Mean monthly local and regional $R_{\mathrm{n}}$ at the Landsat/TERRA and AQUA satellite pass on clear sky days from 2003 to 2005.

computed with the SMC meteorological stations $\left(B-R_{\mathrm{n}}\right.$ ratio regional), 0.84 when the $B$ parameter was estimated using a local $R_{\mathrm{n}}$ ratio computed with the Scots pine stand meteorological station ( $B-R_{\mathrm{n}}$ ratio local), and 0.82 when the $B$ parameter was estimated using the NDVI approach, B-NDVI. It is interesting to note that for the $\mathrm{ET}_{\mathrm{d}}$ models used, the minimum values were always negative. This mainly happens on winter dates when the $R_{\mathrm{n}}$ ratio is also negative. Therefore, on winter dates this methodology should only be used on days when the $R_{\mathrm{n}}$ budget is positive. Errors close to $1 \mathrm{~mm}$ day $^{-1}$ were obtained for the RMSE. Taking into account the range of $\mathrm{ET}_{\mathrm{d}}$ values observed in the studied Scots pine stand (from 0.5 to $2.7 \mathrm{~mm} \mathrm{day}^{-1}$ ), we cannot conclude that the model provides optimal results. When the $R_{\text {nd }}$ ratio is negative during winter, the $\mathrm{ET}_{\mathrm{d}}$ yields negative values and the model does not perform well. Again, it is worth noting that $\mathrm{ET}_{\mathrm{d}}$ models are usually validated on spring or summer dates (Chiesi et al., 2002; Nagler et al., 2005, 2007; Sánchez et al., 2007, 2008a; Verstraeten et al., 2005; Wu et al., 2006) when the daily $R_{\mathrm{n}}$ budget is positive. Our attempt to also estimate $\mathrm{ET}_{\mathrm{d}}$ during autumn and winter has shown the limitations of the method and how $\mathrm{ET}_{\mathrm{d}}$ modelling needs to be further improved, especially in forest areas.

We obtained a better mean RMSE for the different models when only those dates with a positive $R_{\text {nd }}$ ratio were selected, which ranged from 0.5 to $0.7 \mathrm{~mm} \mathrm{day}^{-1}$ with a similar $R^{2}$ (see Tables $2-3$ and Fig. 4). Of the different approaches used to compute the $B$ parameter, the best results were obtained using the local $R_{\mathrm{n}}$ ratio and the NDVI approaches, with a RMSE of 0.5 and $0.6 \mathrm{~mm} \mathrm{day}^{-1}$, respectively, and an estimation error of about $\pm 30 \%$. Indeed, the regional $R_{\mathrm{n}}$ ratio yielded a higher RMSE and estimation error

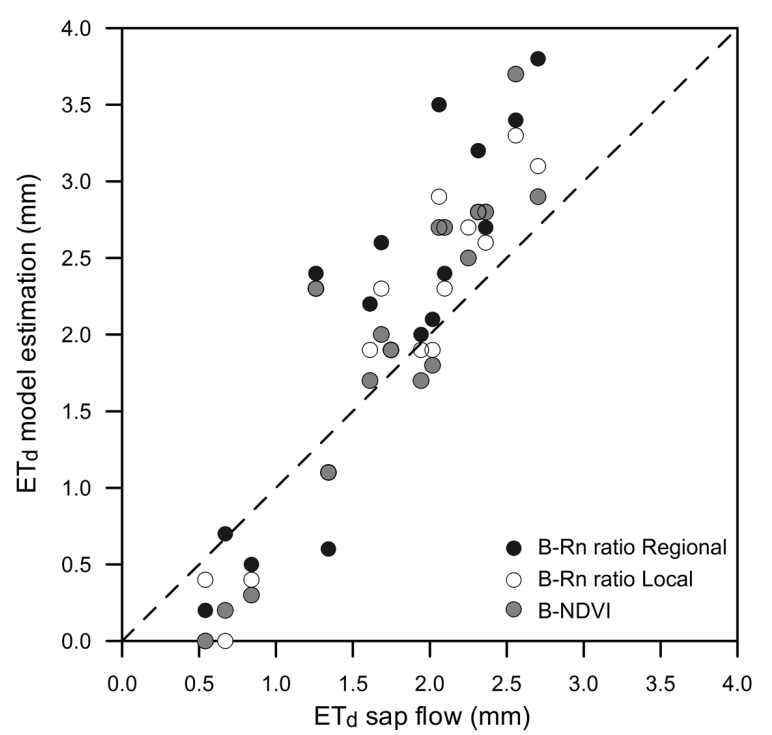

Fig. 4. Relationship between daily evapotranspiration $\left(\mathrm{ET}_{\mathrm{d}}\right)$ calculated from sap flow measurements modelled using Landsat data and the $B$ parameter approach in mm day ${ }^{-1} . B-R_{\mathrm{n}}$ ratio regional is the $B$ approach using the regional $R_{\mathrm{n}}$ ratio, $B-R_{\mathrm{n}}$ ratio local is the $B$ approach using the local $R_{\mathrm{n}}$ ratio and B-NDVI is the $B$ approach using the NDVI.

of about $0.7 \mathrm{~mm} \mathrm{day}^{-1}$ and $\pm 38 \%$ respectively; this could be explained by the differences in the $R_{\mathrm{n}}$ ratio estimation. The regional $R_{\mathrm{n}}$ ratio was computed from the data from the SMC meteorological stations, which are designed for crop assessment and are located in areas at low to medium heights (from 0 to $500 \mathrm{~m}$ ). Our study area is located at $1250 \mathrm{~m}$; therefore, the regional $R_{\mathrm{n}}$ ratio conditions are not representative of our study area. However, it is important to note that optimal $R_{\mathrm{n}}$ ratio values are difficult to obtain because it would be necessary to have a meteorological network with $R_{\mathrm{n}}$ instruments distributed at different altitudes in diverse landscapes. Moreover, $R_{\mathrm{n}}$ instruments are usually found in agrometeorological networks but not very often over forest areas. Although the two $B$ parameter approaches ( $B-R_{\mathrm{n}}$ ratio local and $\left.\mathrm{B}-\mathrm{NDVI}\right)$ obtained similar results, the main advantage of the NDVI approach is easily implemented, when realistic values of NDVI thresholds to compute NDVI* are selected, to compute ET than $B-R_{\mathrm{n}}$ ratio local or regional because that require intensive local calibration. So, if a well-balanced regional $R_{\mathrm{n}}$ ratio is not available due to limitations in the meteorological networks, the NDVI approach is preferable for computing the $B$ parameter at regional scales in an operative way. In all cases, the models tended to overestimate $\mathrm{ET}_{\mathrm{d}}$, showing higher values in the case of the regional $R_{n}$ ratio and lower values in the case of the NDVI approach.

In this study, we are strictly comparing evapotranspiration with stand transpiration of the dominant tree species. As the understory in the studied stand is very poor, the only other contribution comes from soil evaporation, with typical rates 
Table 3. (a): Descriptive statistics of daily net radiation $\left(\mathrm{Rn}_{\mathrm{d}}\right)$ and daily evapotranspiration $\left(\mathrm{ET}_{\mathrm{d}}\right)$ measured over the Scots pine stand, and AQUA MODIS Rn and $\mathrm{ET}_{\mathrm{d}}$ modelled using 3 methods: $B-R_{\mathrm{n}}$ ratio regional, $B-R_{\mathrm{n}}$ ratio local and B-NDVI (see text). (b) Model validation results. s.d. is standard deviation, RMSE is root mean square error and MBE is mean bias error.

\begin{tabular}{|c|c|c|c|c|c|c|c|c|}
\hline & & \multirow[t]{3}{*}{$\begin{array}{c}\mathrm{Rn}_{\mathrm{d}} \\
\text { measured } \\
\left(\mathrm{W} \mathrm{m}^{-2}\right)\end{array}$} & \multirow[t]{3}{*}{$\begin{array}{c}\mathrm{Rn}_{\mathrm{d}} \\
\text { model } \\
\left(\mathrm{W} \mathrm{m}^{-2}\right)\end{array}$} & \multirow[t]{3}{*}{$\begin{array}{c}\mathrm{ET}_{\mathrm{d}} \\
\text { measured } \\
\left(\mathrm{mm} \mathrm{day}^{-1}\right)\end{array}$} & \multicolumn{3}{|c|}{$\begin{array}{c}\mathrm{ET}_{\mathrm{d}} \\
\text { modelled } \\
\left(\mathrm{mm} \mathrm{day}^{-1}\right)\end{array}$} & $n$ \\
\hline & & & & & \multicolumn{2}{|c|}{$B-R_{\mathrm{n}}$ ratio } & \multirow[t]{2}{*}{ B-NDVI } & \\
\hline & & & & & regional & local & & \\
\hline \multirow{4}{*}{ (a) } & Mean & 143 & 148 & 2.1 & 3.7 & 3.9 & 3.8 & \multirow{7}{*}{27} \\
\hline & s.d. & 27 & 41 & 0.7 & 1.7 & 1.6 & 1.7 & \\
\hline & $\min$ & 82 & 62 & 0.9 & 1.3 & 1.6 & 1.2 & \\
\hline & $\max$ & 188 & 251 & 3.6 & 9.0 & 8.9 & 8.9 & \\
\hline \multirow{3}{*}{ (b) } & RMSE & & 22 & & 2.3 & 2.4 & 2.3 & \\
\hline & MBE & & 0 & & 1.6 & 1.8 & 1.7 & \\
\hline & $R^{2}$ & & 0.73 & & 0.06 & 0.05 & 0.03 & \\
\hline
\end{tabular}

of 0.1 to $0.5 \mathrm{~mm} \mathrm{day}^{-1}$ (Poyatos et al., 2007). These values are consistent with the systematic bias between sap flowderived transpiration and the $\mathrm{ET}_{\mathrm{d}}$ models (see Fig. 4).

In addition, it should be stressed that the difficulty of obtaining the effective aerodynamic resistance and the use of a constant value for the analyzed period may have introduced more variability into our analysis, and thus increased the error in the $\mathrm{ET}_{\mathrm{d}}$ models.

\subsubsection{TERRA/AQUA MODIS}

TERRA and AQUA $E_{\mathrm{d}}$ validation did not obtain the same results as Landsat (see Tables 2-3 and Figs. 5-6). In both cases, $\mathrm{ET}_{\mathrm{d}}$ validation showed a higher RMSE, between 1.8 and $2.4 \mathrm{~mm} \mathrm{day}^{-1}$, a low $R^{2}$, between 0.03 and 0.07 and estimation error of about \pm 57 and $50 \%$, respectively. Despite air temperature models also showing good validation results, one possible source of error is the LST. Therefore, it seems that although TERRA/AQUA MODIS LST provides good results in $R_{\text {nd }}$ modelling, this is not the case in $\mathrm{ET}_{\mathrm{d}}$ modelling.

The study area does not cover a $1000 \mathrm{~m} \times 1000 \mathrm{~m}$ pixel, and therefore the remote sensing data, especially the LST, is less representative than a Landsat pixel of 60 (ETM+) or $120 \mathrm{~m}$ (TM). As we mentioned in Sect. 2.1, the study area has high spatial heterogeneity, mosaic of afforestation patches overgrowing old agricultural terraces (Poyatos et al., 2003), at smaller scales than the coarse TERRA/AQUA MODIS pixel, which makes it difficult to validate the $\mathrm{ET}_{\mathrm{d}}$ model results. However, it has to be noted that validating a TERRA/AQUA MODIS in a heterogeneous mountain landscape is not easy due to the extensive instrumentation needed to measure the energy flux in each of the landscape covers. Therefore, it seems that the use of TERRA/AQUA MODIS images themselves in this type of landscape is not enough

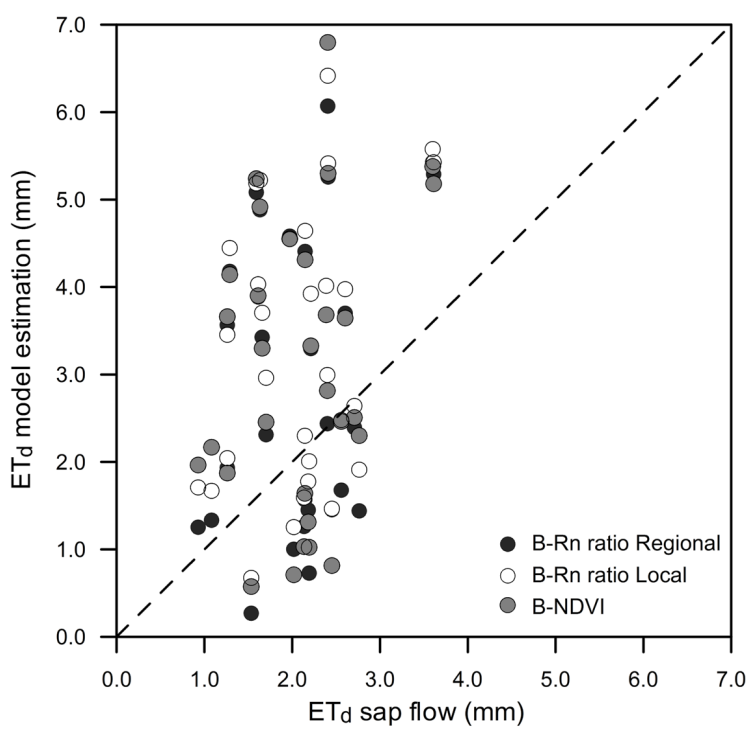

Fig. 5. Relationship between daily evapotransporation $\left(\mathrm{ET}_{\mathrm{d}}\right)$ calculated from sap flow measurements and modelled using TERRA MODIS data and the $B$ parameter estimation in $\mathrm{mm} \cdot$ day $^{-1}$. $B-R_{\mathrm{n}}$ ratio regional is the $B$ approach using the regional $R_{\mathrm{n}}$ ratio, $B-R_{\mathrm{n}}$ ratio local is the $B$ approach using the local $R_{\mathrm{n}}$ ratio and B-NDVI is the $B$ approach using the NDVI.

to accurately map ET on a daily basis. In order to improve the $\mathrm{ET}_{\mathrm{d}}$ results using coarse resolution images, downscaling techniques such as those in Anderson et al. (2004) are required.

There are very few studies in the literature that monitor $\mathrm{ET}_{\mathrm{d}}$ at both high spatial and temporal resolutions during an annual period in a forest area, especially using a large number of Landsat images. In addition, most of the studies to date have dealt with environments subjected to 


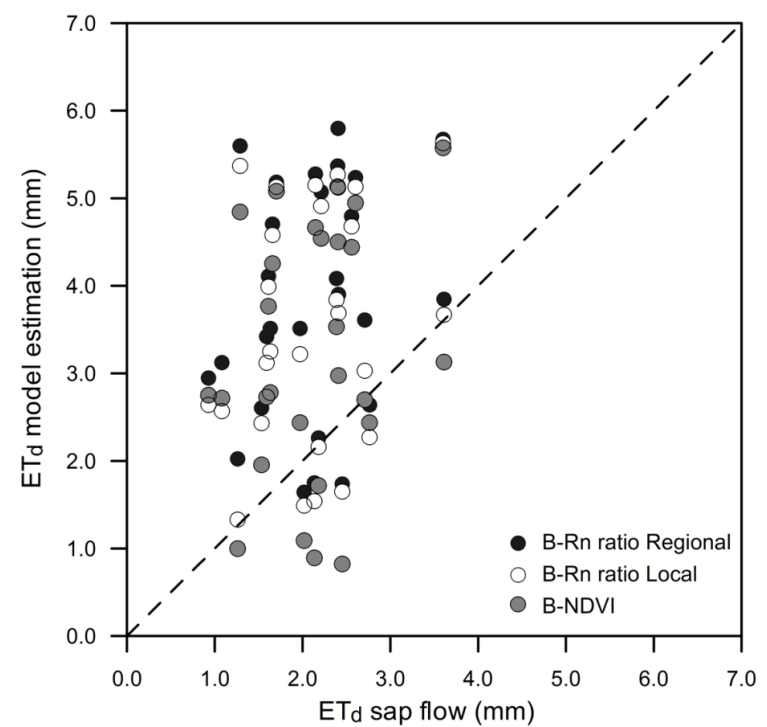

Fig. 6. Relationship between daily evapotransporation $\left(\mathrm{ET}_{\mathrm{d}}\right)$ calculated from sap flow measurements and modelled using AQUA MODIS data and the $B$ parameter estimation in $\mathrm{mm}^{-1}$ day $^{-1}$. $B-R_{\mathrm{n}}$ ratio regional is the $B$ approach using the regional $R_{\mathrm{n}}$ ratio, $B-R_{\mathrm{n}}$ ratio local is the $B$ approach using the local $R_{\mathrm{n}}$ ratio and BNDVI is the $B$ approach using the NDVI.

only mild water stress, such as riparian forests, crops or boreal stands. For example, Wu et al. (2006) reported an RMSE of $0.6 \mathrm{~mm} \mathrm{day}^{-1}$ in a tropical forest using only one Landsat image. They compared their results with estimates from the literature due to the difficulty in validating these kinds of regions using sap flow measurements. Nagler et al. $(2005,2007)$ modelled $\mathrm{ET}_{\mathrm{d}}$ using 8 Landsat-5 TM and about 90 MODIS dates in a cottonwood plantation in riparian corridors of the western US during the July-August period in 2005, and obtained an uncertainty in modelled $\mathrm{ET}_{\mathrm{d}}$ of 20 $30 \%$. Verstraeten et al. (2005) also reported an uncertainty of about $27 \%$ in instantaneous ET modelled with NOAAimagery and validated using EUROFLUX data during the growing seasons of European forests, from March to October. Sánchez et al. (2007) modelled $\mathrm{ET}_{\mathrm{d}}$ using MODIS in a homogeneous Pinus sylvestris stand in the boreal region, and reported an RMSE of $0.81 \mathrm{~mm} \mathrm{day}^{-1}$ and an uncertainty of about $30 \%$ in $\mathrm{ET}_{\mathrm{d}}$ compared to eddy-covariance data. With a more demanding method in terms of ancillary data needs, FOREST-BGC, Chiesi et al. (2002) reported a mean RMSE of $0.4 \mathrm{~mm} \mathrm{day}^{-1}$ introducing LAI derived from 10-day composites of NOAA images in two oak stands. More recently, Sánchez et al. (2008a) obtained a value of $0.7 \mathrm{~mm} \mathrm{day}^{-1}$ in different coniferous, broad-leaf and mixed forests in the Basilicata region with three Landsat-5 TM and ETM+ images from spring and summer.

Overall, for Landsat $\mathrm{ET}_{\mathrm{d}}$ modelling, our results are in agreement with the studies in the literature, as we obtained an uncertainty of about $30 \%$. One positive point of the results of the Landsat $\mathrm{ET}_{\mathrm{d}}$ models across different seasons is the robust $\mathrm{ET}_{\mathrm{d}}$ estimation under varied conditions of water availability, as the studied stand undergoes different degrees of water stress in spring, summer and autumn (Poyatos et al., 2008). However, in the case of MODIS $\mathrm{ET}_{\mathrm{d}}$ modelling, the validation shows a higher RMSE, which suggests that higher spatial resolution is needed for heterogeneous areas.

In addition, it is worth noting that implementing regional models for calculating $T_{\mathrm{a}}$, LST and $R_{\mathrm{Sd} \downarrow}$, as inputs in both $R_{\mathrm{n}}$ and $\mathrm{ET}_{\mathrm{d}}$ modelling has provided good results and made it possible to compute these variables at regional scales with similar accuracy to that in the literature.

It is important to note, however, that we have found some limitations in $\mathrm{ET}_{\mathrm{d}}$ modelling in a mountainous forested area that should be addressed in the future in order to monitor this variable in an operational way. Further work to improve the described methodology should include: (i) the validation of a multi-scale remote sensing model (Anderson et al., 2004) for disaggregating regional fluxes to micrometeorological scales. This would allow $\mathrm{ET}_{\mathrm{d}}$ to be monitored on a daily basis instead of on a 16-day basis thanks to the TERRA/AQUA temporal resolution; (ii) the implementation of methodologies for calculating aerodynamic resistance, such as those described by Norman et al. (1995) and Sánchez et al. (2008a,b).

\section{Conclusions}

The B-method has been used to estimate daily evapotranspiration $\left(\mathrm{ET}_{\mathrm{d}}\right)$ in a Scots pine stand in a mountainous Mediterranean area, obtaining an estimation error of $\pm 30 \%$ (corresponding to $0.5-0.7 \mathrm{~mm} \mathrm{day}^{-1}$ ) using medium spatial resolution imagery, Landsat-5 TM and Landsat-7 ETM+, and the different approaches presented. These results are in agreement with recent studies that used a similar spatial resolution. However, when lower spatial resolution was used (TERRA/AQUA MODIS) the results showed larger errors, 1.9 and $1.7 \mathrm{~mm} \mathrm{day}^{-1}$ respectively.

The $R_{\mathrm{n}}$ ratio emerged as an important parameter to be considered when the B-method is used. Although this ratio is close to 0.3 in spring and summer months, this value is not appropriate for winter and autumn because when the $R_{\mathrm{n}}$ ratio is negative (negative $R_{\mathrm{n}}$ budget) the B-method does not provide a realistic $\mathrm{ET}_{\mathrm{d}}$. Further research is therefore needed to estimate this parameter in these conditions.

The best $\mathrm{ET}_{\mathrm{d}}$ results were obtained using a local $R_{\mathrm{n}}$ ratio approach to calculate the $B$ parameter, followed by the method using NDVI. The regional $R_{\mathrm{n}}$ ratio resulted in larger errors, which means that if a well balanced meteorological network (with $R_{\mathrm{n}}$ sensors) is not available, the NDVI approach is preferable for calculating the $B$ parameter at a regional scale in an operative way.

Regional input variables for calculating $\mathrm{ET}_{\mathrm{d}}$, such as $R_{\mathrm{sd} \downarrow}$, LST and $T_{\mathrm{a}}$, performed well, making possible to compute it at a regional scale with a good level of accuracy. 
Finally, using a large number of remote sensing images that are well distributed over the analyzed period, especially in the case of Landsat, allowed us to better understand the limitations of the methodologies and how to address the further improvement of $\mathrm{ET}_{\mathrm{d}}$ modelling, especially in forest areas.

Acknowledgements. The authors would like to thank our colleagues of the Research Group of Methods in Remote Sensing and GIS (GRUMETS) who collaborated in several ways in image treatment, and Juan Manuel Sánchez from the Department of Earth Physics and Thermodynamics of the University of València for his help in evapotranspiration modelling, and to our colleagues of the Surface Hydrology and Erosion Group - IDAEA for their help in field data acquisition. It would not have been possible to carry out this study without the financial support of the Ministry of Science and Innovation and the FEDER funds through the research project "SCAITOMI (TIN2009-14426-C02-02)". The Catalan Government provided funding to our Research Group for Methods and Applications in Remote Sensing and Geographic Information Systems - "GRUMETS (2009SGR1511)", and "MONTES (CSD2008-00040)". We would like to express our gratitude to the Catalan Water Agency and to the Ministry of the Environment and Housing of the Generalitat (Autonomous Government of Catalonia) for their investment policy and the availability of Remote Sensing data, which has made it possible to conduct this study under optimal conditions. Xavier Pons is recipient of an ICREA Acadèmia Excellence in Research grant.

Edited by: J. Liu

\section{References}

Allen, R. G., Pereira, L. S., Raes, D., and Smith, M.: Crop evapotranspiration, Guidelines for computing crop water requeriments, FAO Irrigation and Drainage Paper, 56, 1998.

Allen, R. G., Tasumi, M., and Trezza, R.: Satellite-based energy balance for mapping evapotranspiration with internalized calibration (METRIC)-Model, J. Irrig. and Drain. E.-ASCE, 133, 395-406, 2007.

Anderson, M. C., Norman, J. M., Mecikalski, J. R., Torn, R. D., Kustas, W. P., and Basara, J. B.: A multi-scale remote sensing model for disaggregating regional fluxes to micrometeorological scales, J. Hydrometeorol., 5, 343-363, 2004.

Baldasano, J. M., Calbó, J., and Moreno J.: Atlas de Radiació Solar a Catalunya (Dades del període 1964-1993), Institut de Tecnologia i Modelització Ambiental (ITEMA), Universitat Politècnica de Catalunya, Terrassa, 1994.

Barry, R. E.: Mountain weather and climate, 2nd edition, Routledge, Taylor and Francis Group, London, 2001.

Bastiaanssen, W. G. M., Meneti, M., Feddes, R. A., and Holtslag, A. A. M.: A remote sensing surface energy balance algorithm for land (SEBAL), 1. Formulation, J. Hydrol., 212-213, 198-212, 1998.

Bates, B. C., Kundzewicz, Z. W., Wu, S., and Palutikof, J. P.: Climate Change and Water, Technical Paper of the Intergovernmental Panel on Climate Change, IPCC Secretariat, Geneva, 2008.
Carlson, T. N. and Buffum, M. J.: On Estimating Total Daffy Evapotranspiration from Remote Surface Temperature Measurements, Remote Sens. Environ., 29, 197-207, 1989.

Carlson, T. N., Caphart, J., and Gillies, R. R.: A new look at the simplified method for remote sensing of daily evapotranspiration, Remote Sens. Environ., 54, 161-167, 1995.

Caselles, V., Sobrino, J. A., and Coll, C.: On the use of satellite thermal data for determining evapotranspiration in patially vegetated areas, Int. J. Remote Sens., 13, 2669-2682, 1992.

Caselles, V., Artiago, M. M., and Hurtado, E.: Maping actual evapotranspiration by combining Landsat and NOAA-AVHRR images: application to the Barrax area, Albacete, Spain, Remote Sens. Environ., 63, 1-10, 1998.

Chander, G., Markham, B. L., and Helder, D. L.: Summary of current radiometric calibration coefficients for Landsat MSS, TM, ETM+, and EO-1 ALI sensors, Remote Sens. Environ., 113, 893-903, 2009.

Chiesi, M., Maselli, F., Bindi, M., Fibbi, L., Bonora, L., Raschi, A., Tognetti, R., Cermak, J., and Nadezhdina, N.: Calibration and application of FOREST-BGC in a Mediterranean area by the use of conventional and remote sensing data, Ecol. Model., 154, 251-262, 2002.

Cristóbal, J., Pons, X., and Serra, P.: Sobre el uso operativo de Landsat-7 ETM+ en Europa, Revista de Teledetección, 21, 5559, 2004.

Cristóbal, J., Pons, X., and Ninyerola, M.: Modelling Actual Evapotranspiration in Catalonia (Spain) by means of Remote Sensing and Geographical Information Systems, Göttinger Geographische Abhandlungen, 113, 144-150, 2005.

Cristóbal, J., Ninyerola, M., and Pons, X.: Modelling air temperature through a combination of Remote Sensing and GIS data, J. Geophys. Res., 13, D13106, doi:10.1029/2007JD009318, 2008.

Cristóbal, J., Jiménez-Muñoz, J. C., Sobrino, J. A., Ninyerola, M., and Pons, X.: Improvements in land surface temperature retrieval from the landsat series thermal band using water vapour and air temperature, J. Geophys. Res., 114, D08103, doi:10.1029/2008JD010616, 2009.

Dilley, A. C. and O'Brien, D. M.: Estimating downward clear sky long-wave irradiance at the surface from screen temperature and precipitable water, Q. J. Roy. Meteorol. Soc., 124, 1391-1401, 1998.

Gallart, F., Llorens, P., Latron, J., and Regüiés, D.: Hydrological processes and their seasonal controls in a small Mediterranean mountain catchment in the Pyrenees, Hydrol. Earth Syst. Sci., 6, 527-537, doi:10.5194/hess-6-527-2002, 2002.

Gallart, F., Latron, J., and Llorens, P.: Catchment dynamics in a Mediterranean mountain environment: the Vallcebre research basins (South Eastern Pyrenees), I: Hydrolog, in: Catchment Dynamics and River Processes: Mediterranean and Other Climate Regions, edited by: Garcia, C. and Batalla, R., Elsevier, Amsterdam, The Netherlands, 1-16, 2005.

García, M., Villagarcía, L., Contreras, S., Domingo, F., and Puigdefábregas, J.: Comparison of Three Operative Models for Estimating the Surface Water Deficit using ASTER Reflective and Thermal Data, Sensors, 7, 860-883, 2007.

Granier, A.: Une nouvelle méthode pur la mesure du flux de sève brute dans le tronc des arbres, Ann. Sci. Fores., 42, 193-200, 1985. 
Hargreaves, G. H. and Samani, Z. A.: Estimating potential evapotranspiration. ASCE, J. Irrig. Drain. Div., 108, 225-230, 1982.

Jackson, R. D., Reginato, R. J., and Idso, S. B.: Wheat canopy temperature: a practical tool for evaluating water requirements, Water Resour. Res., 13, 651-656, 1977.

Jackson, R. B., Carpenter, S. R., Dahm, C. N., McKnight, D. M., Naiman, R. J., Postel, S. L., and Running, S. W.: Water in a changing world, Ecol. Appl., 11, 1027-1045, 2001.

Jung, M., Reichstein, M., Ciais, P., Seneviratne, S. I., Sheffield, J., Goulden, M. L., Bonan, G., Cescatti, A., Chen, J., Jeu, R., Dolman, A. J., Eugster, W., Gerten, D., Gianelle, D., Gobron, N., Heinke, J., Kimball, J., Law, B. E., Montagnani, L., Mu, Q., Mueller, B., Oleson, K., Papale, D., Richardson, A. D., Roupsard, O., Running, S., Tomelleri, E., Viovy, N., Weber, U., Williams, C., Wood, E., Zaehle, S., and Zhang, K.: Recent decline in the global land evapotranspiration trend due to limited moisture supply, Nature, 467, 951-954, 2010.

Kustas, W. P. and Norman, J. M.: Use of remote sensing for evapotranspiration monitoring over land surfaces, Hydrolog. Sci. J., 41, 495-516, 1996.

Kustas, W. P. and Norman, J. M.: A two-source energy balance approach using directional radiometric temperature observations for sparse canopy covered surfaces, Agron. J., 92, 847-854, 2000 .

Kustas, W. P., Moran, M. S., Jackson, R. D., Gay, L. W., Duell, L. F. W., Kunkel, K. E., and Matthias, A. D.: Instantaneous and daily values of the surface energy balance over agricultural fields using remote sensing and reference field in an arid environment, Remote Sens. Environ, 32, 125-141, 1990.

Lagouarde, J. P. and Brunet, Y.: A simple model for estimating the daily upward longwave surface radiation flux from NOAAAVHRR data, Int. J. Remote Sens., 14, 907-925, 1983.

Latron, J., Llorens, P., Soler, M., Poyatos, R., Rubio, C., Muzylo, A., Martínez-Carreras, N., Delgado, J., Regüés, D., Catari, G., Nord, G., and Gallart, F.: Hydrology in a Mediterranean mountain environment - the Vallcebre research basins (northeastern Spain). I. 20 years of investigations of hydrological dynamics, in: Status and Perspectives of Hydrology in Small Basins, IAHS Publ. 336, IAHS Press, Wallingford, UK, 38-44, 2010.

Liang, S.: Narrowband to broadband conversions of land surface albedo, Remote Sens. Environ., 76, 213-238, 2001.

Liang, S., Strahler, A. H., and Walthall, C.: Retrieval of land surface albedo from satellite observations: a simulation study, J. Appl. Meteorol., 38, 712-725, 1999.

Liu, J., Williams, J. R., Zehnder, A. J. B., and Yang, H.: GEPIC - modelling wheat yield and crop water productivity with high resolution on a global scale, Agr. Syst., 94, 478-493, 2007.

Liu, J., Zehnder, A. J. B., and Yang, H.: Global consumptive water use for crop production: The importance of green water and virtual water, Water Resour. Res., 45, W05428, doi:10.1029/2007WR006051, 2009.

Llorens, P., Poyatos, R., Muzylo, A., Rubio, C., Latron, J., Delgado, J., and Gallart, F.: Hydrology in a Mediterranean mountain environment - the Vallcebre research basins (northeastern Spain), III. Vegetation and water fluxes, in: Status and Perspectives of Hydrology in Small Basins, IAHS Publ. 336, IAHS Press, Wallingford, UK, 186-191, 2010.
Mu, Q., Heinsch, F. A., Zhao, M., and Running, S. W.: Development of a global evapotranspiration algorithm based on MODIS and global meteorology data, Remote Sens. Environ., 111, 519536, 2007.

Nadezhdina, N., Èermák, J., and Ceulemans, R.: Radial patterns of sap flow in woody stems of dominant and understory species: scaling errors associated with positioning of sensors, Tree Physiol., 22, 907-918, 2002.

Nagler, P., Cleverly, J., Glenn, E., Lampkin, D., Huete, A., and Wan, Z.: Predicting riparian evapotranspiration from MODIS vegetation indices and meteorological data, Remote Sens. Environ., 94, 17-30, 2005.

Nagler, P., Jetton, A., Fleming, J., Didan, K., Glenn, E., Erker, J., Morino, K., Milliken, J., and Gloss, S.: Evapotranspiration in a cottonwood (Populus frmontii) restoration plantation estimated by sap flow and remote sensing methods, Agr. Forest Meteorol., 144, 95-110, 2007.

Ninyerola, M., Pons, X., and Roure, J. M.: A methodological approach of climatological modelling of air temperature and precipitation through GIS techniques, Int. J. Climatol., 20, 18231841, 2000.

Ninyerola, M., Pons, X., and Roure, J. M.: Objective air temperature mapping for the Iberian Peninsula using spatial interpolation and GIS, Int. J. Climatol., 27(9), 1231-1242, 2007.

Norman, J. M., Kustas, W. P., and Humes, K.: A two-source approach for estimating soil and vegetation energy fluxes from observations of directional radiometric surface temperature, Agr. Forest Meteorol., 77, 263-293, 1995.

ORNL DAAC - Oak Ridge National Laboratory Distributed Active Archive Center: SAFARI 2000 Web Page, http://daac.ornl.gov/ S2K/safari.html, last access: 1 September, 2010.

Oki, T. and Kanae, S.: Global Hydrological Cycles and World Water Resources, Science, 313, 1068-1072, 2006.

Page, J. K.: Prediction of solar radiation on inclined surfaces, Solar energy, R \& D in the European Community, Series F: Solar Radiation Data, 3, Reidel Publishing Company, Dordrecht, 1986.

Palà, V. and Pons, X.: Incorporation of relief into geometric corrections based on polynomials, Photogramm. Eng. Rem. S., 61, 935-944, 1995.

Pons, X. and Ninyerola, M.: Mapping a topographic global solar radiation model implemented in a GIS and refined with ground data, Int. J. Climatol., 28, 1821-1834, 2008.

Pons, X. and Solé-Sugrañes, L.: A Simple Radiometric Correction Model to Improve Automatic Mapping of Vegetation from Multispectral Satellite Data, Remote Sens. Environ., 47, 1-14, 1994.

Poyatos, R., Latron, J., and Llorens, P.: Land-Use and Land-Cover change after agricultural abandonment, The case of a Mediterranean Mountain Area (Catalan Pre-Pyrenees), Mt. Res. Dev., 23, 52-58, 2003.

Poyatos, R., Llorens, P., and Gallart, F.: Transpiration of montane Pinus sylvestris L. and Quercus pubescens Willd. forest stands measured with sap flow sensors in NE Spain, Hydrol. Earth Syst. Sci., 9, 493-505, doi:10.5194/hess-9-493-2005, 2005.

Poyatos, R., Villagarcía, L., Domingo, F., Piñol, J., and Llorens, P.: Modelling evapotranspiration in a Scots pine stand under Mediterranean mountain climate using the GLUE methodology, Agr. Forest Meteorol., 146, 13-28, 2007. 
Poyatos, R., Llorens, P., Piñol, J., and Rubio, C.,: Response of Scots pine (Pinus sylvestris L.) and pubescent oak (Quercus pubescens Willd.) to soil and atmospheric water deficits under Mediterranean mountain climate, Ann. Forest Sci., 65, 306, 2008.

Roerink, G. J., Su, Z., and Menenti, M.: S-SEBI: A simple remote sensing algorithm to estimate the surface energy balance, Phys. Chem. Earth Pt. B, 25, 147-157, 2000.

Rost, S., Gerten, D., Bondeau, A., Lucht, W., Rohwer, J., and Schaphoff, S.: Agricultural green and blue water consumption and its influence on the global water system, Water Resour. Res., 44, W09405, doi:10.1029/2007WR006331, 2008.

Sánchez, J. M., Caselles, V., Niclós, R., Valor, E., Coll, C., and Laurila, T.: Evaluation of the B-method for determining actual evapotranspiration in a boreal forest from MODIS data, Int. J. Remote Sens., 27, 1231-1250, 2007.

Sánchez, J. M., Scavone, G., Caselles, V., Valor, E., Copertino, V. A., and Telesca, V.: Monitoring daily evapotranspiration at a regional scale from Landsat-TM and ETM+ data: Application to the Basilicata region, J. Hydrol., 351, 58-70, 2008a.

Sánchez, J. M., Kustas, W. P., Caselles, V., and Anderson, M. C.: Modelling surface energy fluxes over maize using a two-source patch model and radiometric soil and canopy temperature observations, Remote Sens. Environ., 112, 1130-1143, 2008b.

Schmugge, T. J., Kustas, W. P., Ritchie, J. C., Jackson, T. J., and Rango, A.: Remote sensing in hydrology, Adv. Water Resour., 25, 1367-1385, 2002.

Seguin, B. and Itier, B.: Using midday surface temperature to estimate daily evapotranspiration from satellite IR data, Int. J. Remote Sens., 4, 371-383, 1983.

Siebert, S. and Döll, P.: Quantifying blue and green virtual water contents in global crop production as well as potential production losses without irrigation, J. Hydrol., 384, 198-217, 2010.
Sobrino, J. A. and Raissouni, N.: Toward remote sensing methods for land conver dynamic monitoring: application to Moroco, Int. J. Remote Sens., 21, 353-366, 2000.

Sobrino, J. A., Gómez, M., Jiménez-Muñoz, J. C., Olioso, A., and Chehbouni, G.: A simple algorithm to estimate evapotranspiration from DAIS data: Application to the DAISEX campaigns, J. Hydrol., 315, 117-125, 2005.

Sobrino, J. A., Jiménez-Muñoz, J. C., Sòria, G., Romaguera, M., Guanter, L., Moreno, J., Plaza, A., and Martínez, P.: Land surface emissivity retrieval from different VNIR and TIR sensors, IEEE T. Geosci. Remote, 46, 316-327, 2008.

Verstraeten, W. W., Veroustraete, F., and Feyen, J.: Estimating evapotranspiration of European forests from NOAA-imagery at satellite overpass time: Towards an operational processing chain for integrated optical and thermal sensor data products, Remote Sens. Environ., 96, 256-276, 2005.

Vidal, A. and Perrier, A.: Analysis of a simplified relation for estimating daily evapotranspiration from satellite thermal IR data, Int. J. Remote Sens., 10, 1327-1337, 1989.

Wassenaar, T., Olioso, A., Haseger, C., Jacob, F., and Chehbouni, A.: Estimation of evapotranspiration on heterogeneous pixels, edited by: Sobrino, A. J. A., First International Symposium on Recent Advances in Quantitative Remote Sensing, València, Spain, Publicacions de la Universitat de València, 2002.

Wu, W., Hall, C. A. S., Scatena, F. N., and Quackenbush, L. J.: Spatial modelling of evapotranspiration in the Luquillo experimental forest of Puerto Rico using remotely-sensed data, J. Hydrol., 328, 733-752, 2006. 